Geoffrey D. Dunn

Brisbane

Centre for Early Christian Studies

Australian Catholic University

Geoffrey.dunn@acu.edu.au

\title{
THE CLERICAL CURSUS HONORUM IN THE LATE ANTIQUE ROMAN CHURCH
}

In the first generations of the Christian community we find concern for the personal and professional qualities of those in positions of leadership and ministry. In fact, the deutero-Pauline letters deal explicitly with such matters, as we read in the well-known passages about

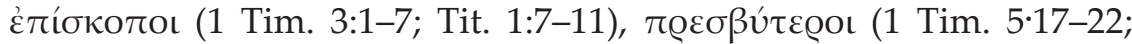

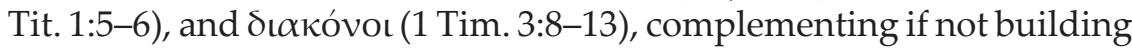
upon the rudimentary information we have from Acts, at least with regard to the last group (Acts 6:1-6). ${ }^{1}$ These passages make it apparent that questions to do with the personal life of ministers, including their marital situation, household management and personal conduct, as well as the length of time since one's conversion before appointment, had become issues in certain communities before the end of the first century. Of course, the issuing of instructions did not end problems about the qualifications and behaviour of those who ministered within the church. From late antiquity we can find any number of letters written from Roman bishops dealing with questions from bishops throughout the West asking about the standards to be expected from leaders within the church. Indeed, these passages from the deutero-Pauline letters feature heavily in their responses as somehow normative.

In the late fourth and early fifth centuries two of the questions that began to feature concern the arrangement of clerical offices into a hierarchy and the promotion between offices within that hierarchy. It was not something that was addressed specifically in the New Tes-

(1) On the question of whether the author of the deutero-Pauline literature saw these three as distinct offices, see R. E. Brown, Priest and Bishop: Biblical Reflections, London, 1971; R. J. Karris, The Pastoral Epistles (New Testament Message, 17), Dublin, 1979, pp. 72-77, 109-110; and F. A. Sullivan, From Apostles to Bishops: The Development of the Episcopacy in the Early Church, New York, 2001, pp. 72-75. 
tament, but the deutero-Pauline passages were employed to address them. In this paper I wish to examine this topic in the correspondence of three Roman bishops from this period: Siricius, Innocent I, and Zosimus, whose letters form the earliest components of medieval canonical decretal collections and lay the foundations for later developments. It shall be my contention that the development of ministerial offices into a clerical cursus honorum and regulating advancement within that system was influenced as much by political and social as by religious considerations, and that within the religious considerations, more attention was given to the broader issue of the importance of a sufficient probationary time spent in minor offices before becoming a bishop than it was to the more specific issue of the proper marital status of clerics, even though this dimension is the one more highlighted in scholarship.

\section{SIRICIUS}

The first letter we may consider comes from Siricius. Written only a few weeks after his election as bishop of Rome at the end of 384, Directa was addressed to the Spanish bishop Himerius of Tarragona (ancient Tarraco in the province of Tarraconensis) in response to a letter he had sent to the now dead Damasus. ${ }^{2}$ The issue of clerical conduct dominates the letter and was of grave concern to both. ${ }^{3}$ What triggered Himerius' enquiry, at least in part, were clerics who fathered children after ordination. ${ }^{4} \mathrm{~A}$ further irregularity concerned the number of wives aspirants to the clerical offices had married, and here the admonition

(2) Siricius, Ep. 1, PL 13.1132-1147 = P. Coustant, Epistolae Romanorum Pontificum et quae ad eos scriptae sunt a S. Clement I usque ad Innocentum III, t. 1, Paris, 1721, cols. 623-638 = P. Jaffé, Regesta Pontificum Romanorum, Bd. 1: A S. Petro ad a. MCXLIII, rev. F. Kaltenbrunner, Leipzig, 1885 (rev. edn) (= JK), no. 355 (11 February, 385).

(3) On this letter recently see C. Hornung, "Siricius and the Rise of Papacy," in The Bishop of Rome in Late Antiquity, ed. by G. D. Dunn, Aldershot, forthcoming; and A. Ferreiro, "Pope Siricius and Himerius of Tarragona (385): Provincial Papal Intervention in the Fourth Century," in The Bishop of Rome in Late Antiquity, ed. by G. D. Dunn, Aldershot, forthcoming.

(4) Siricius, Ep. 1.VII.8-11, PL 13.1138-1141. See Peter Brown, The Body and Society: Men, Women, and Sexual Renunciation in Early Christianity (Lectures on the History of Religions, new series, 13), New York, 1988, pp. 357-359; and S. HeID, Celibacy in the Early Church: The Beginnings of a Discipline of Obligatory Continence for Clerics in East and West, trans. M. J. Miller, San Francisco, 2000 
from 1 Timothy about being the husband of only one wife was employed, and an interpretation of just what that passage meant was offered. ${ }^{5}$

It was at this point, after having outlined the problem, that Siricius made his comments about the clerical cursus honorum, linking it to the previous section of his letter with itaque, suggesting that what he was about to write depended upon the problem that had just been outlined. ${ }^{6}$ While some have commented upon this passage in Siricius' letter, what I want to highlight is how Siricius' stipulations about clerical advancement through the ranks only being for those married once only was of particular concern to Spain. ${ }^{7}$

Just what did Siricius set out? David Hunter has drawn attention to the fact that Siricius actually offers three cursus honorum: one for those initiated in infancy, one for those who came to Christianity in their adult life, and one for monks. ${ }^{8}$ For the first group, the office of lector could be conferred before puberty and, provided one then only married once, and married a virgin, one could be promoted to acolyte and subdeacon at adolescence and fulfil this/these offices until the age of thirty. At that point, again provided that the provisions of clerical continence were met, one could be promoted to deacon. After five years as deacon one could become presbyter, and ten years after that one was eligible to be made a bishop (which can be worked out as being at the age of forty-five), again provided that he has lived a worthy life. ${ }^{9}$

(Eng. edn), pp. 217-223, although I would not necessarily agree with his interpretation about papal authority.

(5) Siricius, Ep. 1.VIII.12, PL 13.1141.

(6) Ibid., 1.IX.13, PL 13.1142-1143.

(7) See A. Faivre, Naissance d'une hiérarchie. Les premières étapes du cursus clérical (ThH, 40), Paris, 1977, pp. 316-318.

(8) D. G. Hunter, "Clerical Marriage and Episcopal Elections in the Latin West," in Episcopal Elections in Late Antiquity, ed. by J. Leemans, P. Van Nuffelen, S. W. J. Keough, and C. Nicolaye (AK, 119), Berlin, 2011, pp. 183 202 (193).

(9) Siricius, Ep. 1.IX. 13, PL 1142-1143: "Quicumque itaque se ecclesiae uouit obsequiis a sua infantia, ante pubertatis annos baptizari, et lectorum debet ministerio sociari. Qui accessu adolescentiae usque ad tricesimum aetatis annum, si probabiliter uixerit, una tantum, et ea, quam uriginem communi per sacerdotem benedictione perceperit, uxore contentus, acolythus et subdiaconus esse debebit: postque ad diaconii gradum, si se ipse primitus continentia praeeunte dignum probarit, accedat. Vbi si ultra quinque annos laudabili- 
Underpinning these steps is the very real and specific concern about clerical marital continence. Indeed, although there is mention of what could be a wide-ranging series of conditions, it is obvious here that integritas uitae has been reduced in practice to only one: conformity to marital norms. Having such a system of promotions in place should ensure that no one became bishop whose lifestyle was unacceptable. For the second group, although the idea of a cursus remained, it was abbreviated. One could be made lector or exorcist upon initiation and acolyte and subdeacon two years later, again providing that one met the acceptable marital conditions. After five years one could become deacon and sometime after that one became eligible to be elected presbyter or bishop..$^{10}$ Just to emphasise that this cursus honorum was designed to overcome the specific problem of men becoming bishops who had been married more than once (or married to a non-virgin, i.e. a previously married woman), penalties for doing so feature in the next section of the letter. ${ }^{11}$ These first two groups mirror what we find in Dominus inter, a letter addressed to the Gallic bishops, and which I accept as having been written by Siricius' predecessor, Damasus. ${ }^{12}$ There is a difference, however, in that in this earlier letter, while both those initiated in infancy and in maturity can both become clerics, provided they have been chaste (virginal in the first instance and only married once in the second), there is no reference to a cursus. ${ }^{13}$

ter ministrarit, congrue presbyterium consequatur. Exinde, post decennium, episcopalem cathedram poterit adipisci, si tamen per haec tempora integritas uitae ac fidei eius fuerit approbata."

(10) Siricius, Ep. 1.X.14, PL 13.1143: “Qui uero iam aetate grandaeuus, melioris propositi conuersione prouocatus, ex laico ad sacram militiam peruenire festinat, desiderii sui fructum non aliter obtinebit, nisi eo quo baptizatur tempore, statim lectorum aut exorcistarum numero societur, si tamen eum unam habuisse uel habere, et hanc uirginem accepisse, constet uxorem. Qui dum initiatus fuerit, expleto biennio, per quinquennium aliud acolythus et subdiaconus fiat, et sic ad diaconium, si per haec tempora dignus iudicatus fuerit, prouehatur. Exinde iam accessu temporum, presbyterium uel episcopatum, si eum cleri ac plebis edecumarit electio, non immerito sortietur."

(11) Siricius, Ep. 1.XI.15, PL 13.1143-1144.

(12) Y.-M. Duval, La décrétale Ad Gallos Episcopos: son texte et son auteur. Texte critique, traduction française et commentaire (VC Supp., 73), Leiden and Boston, 2005.

(13) [Damasus], Dominus inter III.8 (Duval, La décrétale Ad Gallos Episcopos, p. 36). This sense of development in Siricius would be another reason I support the assigning of Dominus inter to Damasus. 
The third group were monks, and the aforementioned problem of marriages was not mentioned because presumably those who entered the monastic life were virginal and not married or widowed. Monks under thirty were to progress through the minor orders before diaconate and presbyterate, and the episcopate was only possible for those who had spent time in those ranks. ${ }^{14}$

There are unanswered questions in the system proposed by Siricius. To what extent was he creating something new or codifying the current Roman practice? ${ }^{15}$ Had acolyte and subdeacon been merged into one office at this stage? What about the office of exorcist for those baptized in their youth? Is the apparent difference in the first two systems with regard to the next step after diaconate (to presbyterate for those initiated young and to presbyterate or episcopate for those initiated in their mature years) intended ${ }^{16}$ What was the length of time in the subdiaconate in the first system and the length of time in the diaconate in the second? However, we may leave these aside for our purposes.

Although the question of clerical marriage was the context in which Himerius asked his question and Siricius offered his response (indeed, a cleric's marital situation is the only criterion mentioned upon which to judged a cleric's worthiness for promotion, and from Jerome we

(14) Siricius, Ep. 1.XIII.17, PL 13.1144-1145: "Monachos quoque quos tamen morum grauitas et uitae ac fidei institutio sancta commendat, clericorum officiis aggregari et optamus et uolumus; ita ut qui intra tricesimum aetatis annum sunt, in minoribus per gradus singulos, crescente tempore, promoueantur ordinibus: et sic ad diaconatus uel presbyterii insignia, maturae aetatis consecratione, perueniant. Nec saltu ad episcopatus culmen ascendant, nisiin his eadem, quae singulis dignitatibus superius praefiximus, tempora fuerint custodita."

(15) While we have information that Cornelius, one of Siricius' predecessors in Rome, had climbed up the clerical ranks before becoming bishop in 251 (Cyprian, Ep. 55.8.2, ed. by G. F. Diercks, [CCL, 3B], Turnhout, 1994, p. 264), we cannot be sure if Cyprian was engaging in hyperbole at this point nor whether Cornelius' experience was a common one. Duval, La décrétale Ad Gallos Episcopos, p. 88, thinks that Siricius established it, while I would be more inclined to think that he merely reflected Roman practice.

(16) J. St. H. Gibaut, Sequential or Direct Ordination? A Return to the Sources (Alcuin/GROW Joint Liturgical Studies, 55), Cambridge, 2003, p. 19, that Siricius mandated in every case that the next step after the diaconate was the presbyterate. 
know examples of this problem from Spain), ${ }^{17}$ if Siricius' solution of outlining a cursus honorum reflected what existed in Rome already, then it might well have developed there in a different context.

Is it possible that Ambrose's rapid promotion in 374 (not any concern about his marital situation) might have triggered the church of Rome thinking about this issue in the Italian context, for the bishop of Milan had reached that office when he had not even completed Christian initiation? ${ }^{18}$ It is certainly true that by this time there was a slowly increasing number of Christians from a privileged background, people who participated in the Roman political process at the higher levels, who were becoming clerics. Their background made them natural candidates for leadership positions within the Christian community, and they were used to and probably expected there to be a Christian cursus honorum to match the political one. At the same time, given their social standing, they would have expected to rise rapidly through any such system (although perhaps not as rapidly as had Ambrose). ${ }^{19}$ Imperial efforts to stop curiales from joining the ranks of the clergy and avoid their financial obligations to the state attest to the influx of high-status men to the ranks of the clergy, and the fact that there needed to be imperial legislation suggests large numbers..$^{20}$ If the Roman church had

(17) Jerome, Ep. 69.2-5, ed. by I. Hilberg (CSEL, 54), Vienna, 19962, pp. 680-689. On this see D. G. Hunter, "The Raven Replies: Ambrose's Letter to the Church at Vercelli (Ep. ex. coll. 14) and the Criticisms of Jerome," in Jerome of Stridon: His Life, Writings and Legacy, ed. by A. CaIn and J. LössL, Farnham, 2009, pp. 175-189 (182-183). Interestingly Jerome goes on to attack neophtyes who become bishops.

(18) See N. B. McLynn, Ambrose of Milan: Church and Court in a Christian Capital (TCH, 22), Berkeley, 1994, pp. 44-52.

(19) See C. Sotinel, "Le recrutement des évêques en Italie aux IVe et $V^{e}$ siècles: essai d'enquête prosopographique," in Vescovi e pastori in epoca teodosiana, XXV Incontro di studiosi dell'antichità cristiana, Roma, 8-11 maggio 1996 (SEA, 58), Rome, 1997, pp. 193-204; and C. Sotinel, "Le évêques italiens dans la société de l'Antiquité tardive: l'émergence d'une nouvelle élite?" in Le trasformazioni delle elite nel tardoantico, ed. by R. Lizzi (Saggi di storia antica, 25), Rome, 2006, pp. 377-404.

(20) Cod. Theod. 16.2.2-15, ed. by Th. Mommsen and P. Krüger, Codex Theodosianus, vol. 1/2: Libri XVI cum Constitutionibus Sirmondianus, Hildsheim, 1990, pp. 835-840. See A. Di Berardino, "The Poor must be Supported by the Wealth of the Churches (Codex Theodosianus 16.2.6)," in Prayer and Spirituality in the Early Church, vol. 5: Poverty and Riches, ed. by G. D. Dunn, D. LuckensMEYer, and L. Cross, Strathfield, NSW, 2009, pp. 249-268. 
developed a clerical cursus honorum some time in the past it could have been devised to slow the rapid promotion of those who were novices in the Christian faith, men like Ambrose in Milan. Although Ambrose was a success in managing his church, obviously there must have been others who were not, despite their background. Dennis Trout thinks that the violation of the cursus by Paulinus of Nola could explain why he was not treated well by Siricius when he visited Rome. ${ }^{21} 1$ Timothy 3:6 had specifically forbidden bishops to be new converts, although no explanation was given as to why, and 1 Timothy 5:22 had warned that hands were to be laid on no one too readily. Well before Ambrose, the Council of Nicaea in 325 had banned the ordination of neophytes as bishops, so the issue was not new and not confined to Rome..$^{22}$ Certainly the Synod of Sofia (ancient Serdica in the province of Dacia Mediterranea) in 343 had legislated that wealthy individuals and those with a background in civil administration needed to advance through clerical ranks from lector to deacon to presbyter to bishop in order that someone be tested and found worthy. ${ }^{23}$

That something like that was the original context seems reasonable given that Siricius outlined the second stream for recent converts, and explicitly mentions that these were people who expected to be in ministerial positions of leadership. ${ }^{24}$ Just what that worthiness consisted of seems not to have been spelled out originally, although no doubt one's marital situation would have been implicitly included, but only as one of a number of stipulations. The situation in Spain concerning marriage irregularities might well have been a new context, but it enabled the marital situation to become a more explicit part of a system that required the regular scrutiny over time of those who would reach the

(21) D. Trout, Paulinus of Nola: Life, Letters, and Poems, Berkeley, 1999, p. 114. See Paulinus of Nola, Ep. 5.13-14, ed. by G. De Hartel and M. Kamptner (CSEL, 29), Vienna, $1999^{2}$, p. 33.

(22) Council of Nicaea, can. 2, ed. by G. Alberigo et al., The Ecumenical Councils from Nicaea I to Nicaea II (325-787) (Corpus Christianorum, Conciliorum Oecumenicorum Generaliumque Decreta, 1), Turnhout, 2006, pp. 20-21.

(23) Synod of Sofia (Serdica), can. 13, ed. by H. Hess, The Early Development of Canon Law and the Council of Serdica (OECS), Oxford, 2002, p. 220 - the Latin version; can. X, ed. by Hess, The Early Development, pp. 232-234 - the Greek version.

(24) Siricius, Ep., 1.X.14, PL 13.1143: “...ex laico ad sacram militiam peruenire festinat, desiderii sui fructum non aliter obtinebit, nisi eo quo baptizatur tempore, statim lectorum aut exorcistarum numero societur..." 
highest ranks of ecclesiastical ministry. ${ }^{25}$ Such a distinction between the concerns over marriage in Spain and the concerns over rapid promotion in Rome both being reflected in the one letter has not been noticed by scholars like Hunter. ${ }^{26}$

\section{INNOCENT I}

From here we may turn to the comments found in the letters of one of Siricius' close successors, Innocent I (402-417). Interestingly, it appears he was elected bishop from the rank of Rome's deacons. ${ }^{27}$ This was not uncommon in Rome, ${ }^{28}$ indeed Siricius had been a deacon before becoming Rome's bishop..$^{29}$ It should not have happened under Siricius' scheme unless both Siricius and Innocent were older converts to Christianity. Rather than suggest that they were, it would seem to me that the regulations Siricius set before Himerius were not as hard and fast as they appear to us.

We have a letter from Innocent to Felix, bishop of Nocera, somewhere in Italy, ${ }^{30}$ sometime during his episcopate. Felix had asked about

(25) If this were the case then one may need to qualify, in part, the assertion made by K. Sessa, The Formation of Papal Authority in Late Antiquity: Roman Bishops and the Domestic Sphere, Cambridge, 2012, p. 179, that Siricius integrated the clerical household into the emerging institution of the church. This is true, but if the stipulations about marriage were not the original focus in the formulation of the cursus but were emphasized by Siricius for the Spanish churches, then the original concern was not about clerical households in Rome but about the worthiness of the minister in general terms being proven over time.

(26) D. G. Hunter, Marriage, Celibacy, and Heresy in Ancient Christianity: The Jovinianist Controversy (OECS), Oxford, 2007, pp. 211-213.

(27) G. D. Dunn, "Anastasius I and Innocent I: Reconsidering the Evidence of Jerome," VC, 61 (2007), pp. 30-41.

(28) G. D. Dunn, “Deacons in the Early Fifth Century: Canonical Developments under Innocent I," in: Diakonia, diaconiae, diaconato: semantica e storia nei padri della chiesa, XXXVIII Incontro di studiosi dell'antichità cristiana, Roma 7-9 maggio 2009 (SEA, 117), Rome, 2010, pp. 331-340 (335-336).

(29) Damasus, Epigr. 93.1-2, ed. by М. Інм, Damasi epigrammata accedunt Pseudodamasiana aliaque ad Damasiana inlustranda idonea, Anthologiae Latinae Supplementa, vol. 1, Leipzig, 1895, p. 96.

(30) Innocent I, Ep. 37, PL 20.603-605 = Coustant, Epistolae Romanorum Pontificum, cols. 910-912 = JK 314. On the various possible locations of Felix see DunN, "Deacons in the Early Fifth Century," p. 331, n. 1. 
eligibility for admission to the clergy, particularly with regard to those who mutilate themselves, those who are twice-married, and those who have held certain civil offices. ${ }^{31}$ With regard to the latter group Innocent refers specifically to this impediment applying to those joining the priesthood (sacerdotium) or the clerical office (clericatum). ${ }^{32}$ Innocent goes on to mention several clerical offices - lector, acolyte, deacon, and priest (sacerdos) - and the need to test a candidate's worthiness for holding important offices (ad sacerdotium) by the time they spent in the minor offices (in minoribus officiis) and the fact that no one is to reach any of these offices quickly. ${ }^{33}$ This last comment reminds us of what is to be found in 1 Timothy 5:22. Although Innocent says he is following the lead of his predecessors he nowhere says, as I have pointed out elsewhere, that one needed to hold each and every one of the listed offices (to say nothing of the unlisted offices). There certainly is a sense of an expected cursus honorum, but my specific point elsewhere was to indicate that Innocent did not mandate that one needed to be a presbyter before becoming a bishop, the implication being that one could become bishop from the ranks of either the diaconate or the presbyterate, as indeed was the case in Rome, Innocent himself being a probable example. ${ }^{34}$

Interestingly, although Innocent had made comment about the issue of clerical marriage earlier in this brief letter, when speaking of the cursus he did not refer to it. The judgement about one's suitability for advancement was not specified as to whether or not a cleric was able to live an upright, i.e. maritally acceptable, life; all that is said is that they must had made a valuable contribution in their ministerial

(31) Innocent I, Ep. 37.I.3, PL 20.603-604, for mutilation, 37.II.4, PL 20.604, for twice-married clerics, and 37.III.5, PL 20.604, for unacceptable previous occupations. Being a twice-married man was not only an impediment (1 Tim. 3:2) but so was being married to a twice-married woman (Lev. 21:13-14). For more on the impeding offices in Innocent's thought see Duval, La décrétale Ad Gallos Episcopos, pp. 108-109; and G. D. DunN, "Canonical Legislation on the Ordination of Bishops: Innocent I's Letter to Victricius of Rouen," in Episcopal Elections in Late Antiquity, ed. by J. Leemans, P. Van Nuffelen, S. W. J. Keough, and C. Nicolaye (AK, 119), Berlin, 2011, pp. 145-166 (159-164).

(32) See Dunn, "Deacons in the Early Fifth Century," p. 332, n. 3 for the ways in which Innocent used the term sacerdos. I am presuming in this instance it refers to both bishops and presbyters.

(33) Innocent I, Ep. 37.V.6, PL 20.604-605.

(34) Dunn, “Deacons in the Early Fifth Century,” p. 335. 
activity (postea emensis stipendiorum meritis ueniant). ${ }^{35}$ The context here is those who have held prior civil office. The political realities of where clerics are recruited from lies behind this letter. This is a point not noted in Faivre's study. ${ }^{36}$

In a letter to the Spanish bishops who had been at the Synod of Toledo in 400 Innocent addressed the question of clerical qualifications. ${ }^{37}$ This was obviously a topic of some currency in Spain. It is almost certainly to be dated prior to the letter to Felix. Innocent presented the list of circumstances that ought to debar someone from entering the clergy: having served in the military, having been an advocate, having served in the imperial administration, being from the curiales (both because of the imperial likelihood of them being called back to their responsibilities there and because to fulfil their municipal offices they would have been involved in pagan cults), ${ }^{38}$ as well as a list of necessary qualities: someone who has become a lector at the appropriate age having been initiated in infancy or someone who became Christian at an older age assuming clerical office, if married then married to a virgin and married himself only once, with reference to 1 Timothy 3:2 (and the debate in Spain about whether a wife married before a man's baptism counted as a wife after he was baptized was answered in the affirmative). ${ }^{39}$ The cursus is presumed, but not presented in detail. The particular situation in Spain, which still centred around questions of clerical marriage, receives some prominence in Innocent's response, but it is balanced by other concerns, reflecting the Roman holistic approach, rather than the particular Spanish emphasis.

\section{Zosimus}

The final example I wish to consider comes from Innocent's successor, Zosimus. On 21 February, 418 the Roman bishop responded to a letter from Hesychius, bishop of Solin (ancient Salona in the province of

(35) Innocent I, Ep. 37.V.6, PL 20.605. On this letter see G. D. DunN, "Innocent I and the First Synod of Toledo," in The Bishop of Rome in Late Antiquity, ed. by G. D. Dunn, Aldershot, forthcoming.

(36) Faivre, Naissance d'une hiérarchie, pp. 321-326.

(37) Innocent I, Ep. 3, PL 20.485-493 = Coustant, Epistolae Romanorum Pontificum, cols. 763-771 = JK 286.

(38) Innocent I, Ep. 3.VI.9, PL 20.492.

(39) Innocent I, Ep. 3.VI.10, PL 20.492-493. 
Dalmatia). ${ }^{40}$ Zosimus notes that he has written on this topic before in letters sent to Gaul, Spain, and Africa. Indeed, in Epistula 7 to Patroculus of Arles, written on 20 September, 417 we find such information. ${ }^{41}$ He is surprised that Hesychius had not been informed at that time about Rome's thinking on this, but was quite prepared to spell it out for him in this letter. ${ }^{42}$

While there is brief mention of the marital condition of clergy (and their need not to be a penitent and the possible mention of their not being married to a widow) as a prerequisite for promotion, this actually has very little place in Zosimus' thinking as expressed to Hesychius. ${ }^{43}$ The main concern is with ensuring that a person who is promoted to senior ministerial positions is well trained and experienced in the ministry. The purpose of probation is to instil ecclesiastical discipline. ${ }^{44}$

(40) Zosimus, Ep. 9, PL 20.669-673 = Coustant, Epistolae Romanorum Pontificum, cols. 968-971 = JK 339. On the Christian history of Solin see V. B. Prozorov, "The Passion of St. Domnius: The Tradition of Apostolic Succession in Dalmatia," Scr, 2 (2006), pp. 219-239. On p. 229 Prozorov doubts that the evidence from Zosimus' letter indicates that Hesychius was metropolitan.

(41) Zosimus, Ep. 7, PL 20. 668-669 = Coustant, Epistolae Romanorum Pontificum, cols. 961-962 = JK 333.

(42) Zosimus, Ep. 9.I.1, PL 20.670. As noted by E. Caspar, Geschichte des Papsttums von den Anfängen bis zur Höhe der Weltherrschaft, Bd 1: Römische Kirche und Imperium Romanum, Tübingen, 1930, p. 304, miramur, the term used here by Zosimus, was frequently used by Innocent I with Italian bishops for whom he was metropolitan or who were in his prefecture and for whom he was a close point of appeal. It should not surprise us that Zosimus used it with the metropolitan of Solin, since Illyricum Occidentale was part of the prefecture over which the Roman bishop exercised primatial authority, if we may employ this term.

(43) Zosimus, Ep. 9.III.5, PL 20.673: “...ut neque digamus, neque poenitens [neque uiduae maritus]." On the textual problems of this section, including whether the text ought to read digamus (Coustant) or bigmaus and include the phraise neque uiduae maritus see R. GeIsInger, On the Requirement of Sufficient Maturity for Candidates to the Presbyterate (c. 1031 \$1), with a Consideration of Canonical Maturity and Matrimonial Jurisprudence (1989-1990) (Tesi Gregoriana, Serie Diritto Canonico, 35), Rome, 1999, p. 85, n. 23. A more thorough investigation of the MSS is called for.

(44) Zosimus, Ep. 9.I.1, PL 20.670: “...ne quis penitus contra patrum praecepta, qui ecclesiasticis disciplinis per ordinem non fuisset imbutus, et temporibus approbatione diuinis stipendiis eruditus, nequaquam ad summum ecclesiae sacerdotium aspirare praesumeret..." 
To hold a senior position one needs to have been tested and proven in more junior ones, just as in the civil service or army (and the Christian community is called a heavenly militia). ${ }^{45}$ It would be fair to say that the idea of the church ministerial hierarchy matching that of the imperial administration finds full flower in Zosimus.

The principal concern is with the quality of bishops. The purpose of the cursus honorum (and Zosimus lists lector, exorcist, acolyte, subdeacon, and deacon, noting that one should not leap over [saltio] any of them, before the high ranks of presbyter and bishop [pontifex]) was to ensure good quality bishops who had many years of ministerial experience. We find Zosimus arguing that presbyters ought to be of an age where their age matches what the word "elder" means. ${ }^{46} \mathrm{Zo}-$ simus even offers an explanation as to why too many clerics are ordained: to provide bishops with large retinues or seemingly important dioceses. ${ }^{47}$

In terms of the intervals between clerical offices, Zosimus, like Siricius, distinguished between those initiated in infancy and those who became Christian at a more mature age. For the first group, they were to be lectors until aged twenty, while the second group were to be either lectors or exorcists for a period of no less than five years. After this one (and there seems to be no longer any distinction in terms of when one was initiated), one could become acolyte or subdeacon for a period of four years. Then one needed to be a deacon for five years (as in Siricius) before becoming a presbyter. Finally, after an unspecified time and at an unspecified age one could become bishop, provided one were suitable. ${ }^{48}$ There are a number of differences between the intervals and ages set out by Siricius and Zosimus, but they are not neces-

(45) Zosimus, Ep. 9.I.2, PL 20.671: “Si enim officia saecularia principem locum, non uestibulum actionis ingressis, sed per plurimos gradus examinato temporibus deferunt: quis ille tam arrogans, tam impudens inuenitur, ut in coelesti militiae, quae pensius ponderanda est, et sicut aurum repetitis ignibus exploranda, statim dux esse desideret, cum tyro ante non fuerit, et prius uelit docere, quam discere?"

(46) Zosimus, Ep. 9.I.2, PL 20. 671: "Iam uero ad presbyterii fastigium talis accedat, ut et nomen aetas impleat, et meritum probitatis stipendia anteacta testentur."

Zosimus, Ep. 9. I.3, PL 20.671-672.

(48) Zosimus, Ep. 9.III.5, PL 20.672-673. 
sarily inconsistent with each other at any point, ${ }^{49}$ except with regard to the cursus for the mature candidate..$^{50}$

\section{Africa}

Just for the sake of comparison, one may note that at their synod in Carthage on 25 May, 419, as well as considering the question of Apiarius and the unwelcome involvement of the Roman church in the person of both Zosimus and his successor Boniface $\mathrm{I}^{51}$ the African bishops made comments relevant to the clerical cursus honorum. They too seemed to have a system where lectors were selected while children, for it was decided that when they reached puberty they should either marry or commit to continence..$^{52} \mathrm{~A}$ minimum age was set of twenty-five for deacons (as well as for the consecration of virgins, incidentally), some five years younger than what Siricius had stated to Himerius. While the Africans produced many canons regulating clerical life this was all they said on the advancement of clergy through the ranks, from which one must conclude that this had not been a disputed topic in Africa and that the African bishops did not feel compelled to create uniform practice.

\section{Conclusion}

We could continue our investigation with other Roman bishops later in the fifth century, like Leo and Gelasius, but what we have seen is suf-

(49) L. J. Patsavos, A Noble Task: Entry into the Clergy in the First Five Centuries, trans. N. Russell, Brookline, MA, 2007 (Eng. ed.), p. 275, is incorrect when he writes: "But while Siricius sets out age limits for the different grades of the clergy, Zosimus specifies how long the ministry in each grade should last." Both authors have a mixture of both.

(50) In Siricius one was to be a lector/exorcists for two years before becoming acolyte/subdeacon for five years before becoming deacon. Sometime later one could become presbyter or bishop. In Zosimus one was to be lector/ acolyte for five years, and acolyte/subdeacon for four years, and then deacon for five years. Perhaps the continuing experience of too many poorly trained mature-aged men becoming bishops was the reason for this lengthening of probation under Zosimus.

(51) See J. E. Merdinger, Rome and the African Church in the Time of Augustine, New Haven and London, 1997, pp. 111-135; and G. D. Dunn, "The Appeal of Apiarius to the Transmarine Church of Rome," Journal of the Australian Early Medieval Association, 8 (2012), pp. 9-30.

(52) Synod of Carthage (25 May, 419), can. 16, ed. by C. Munier (CCL, 149), Turnhout, 1974, p. 105. 
ficient to draw conclusions, particularly as later Roman bishops repeat what had been said by their predecessors. The scriptural injunctions found in the pseudo-Pauline pastoral letters played an important part in the patterns of ministry employed in the late-antique church. The various ministries found in the New Testament had developed into a hierarchy, with various offices becoming stepping-stones to the next. This mirrored the civil practice of magistracies and was perhaps influenced by it. As concerns were raised by the early fourth century about the quality of men who were becoming bishops, in particular new converts from the higher classes of imperial society like the curiales, the church responded by making use of this hierarchy of offices, insisting that candidates progress through the ranks and spend time at each level to build up their experience and prove their suitability.

Part of that suitability was a candidate's adherence to an acceptable marital situation: being once married to a woman also only once married. That particular concern was central to the enquiry from the Spanish bishop, Himerius, and to Siricius' reply, but a careful reading of Siricius' own letter and that of his two successors considered here reveals that the situation of prime concern in Rome was that of the rapid advancement of inexperienced men to the office of bishop. While the letters from the Roman bishops give the impression of a rigid system that was certainly not the case in practice, as the promotion of both Siricius and Innocent to Rome's episcopacy from the diaconate attests.

This paper has demonstrated that both a sense of fidelity to the religious imperatives of the Scriptures, as well as the influence of political and social concerns from the wider society shaped the development of a clerical cursus honorum in late antiquity.

\section{SUMMARY}

We have evidence from late antique Rome in letters from three of its bishops (Siricius, 384-399, Innocent I, 402-417, and Zosimus, 417-418) of a transformation of the scriptural understanding of ministry as service into a clerical cursus honorum, a career pathway that paralleled what could be found in government or the imperial bureaucracy. It could be argued that the influx of curiales into clerical ranks (despite imperial restrictions), the need for experienced leaders within the church, and the increasing insistence on clerical sexual continence contributed to this development. The experience was not only to be in administration but in living the Christian life. This paper examines the model of clerical office as dictated by these Roman bishops and argues that political together with religious considerations shaped their directives as they responded to what they perceived as abuses. 